\title{
ANALISIS AKUNTABILITAS BERBASIS SHARIA ENTERPRISE THEORY UNTUK PENGEMBANGAN BISNIS RUMAH JAHIT AKHWAT DI MAKASSAR
}

\section{ACCOUNTABILITY ANALYSIS BASED ON SHARIA ENTERPRISE THEORY FOR THE DEVELOPMENT OF RUMAH JAHIT AKHWAT IN $M A K A S S A R$}

\section{Sri Ujiana Putri}

Sekolah Tinggi Ilmu Islam dan Bahasa Arab (STIBA) Makassar

Email: sri.ujiana@stiba.ac.id

Keywords :
Accountability, Business, Sharia,
SET, RJA

SET, RJA

\begin{abstract}
This study aimed to determine the business management system implemented by the Rumah Jahit Akhwat (RJA) including the implementation and role of accountability based on Sharia Enterprise Theory (SET). This study used a qualitative method with a phenomenological approach. The subjects of this research are the owner, employees, and customers of RJA through direct observations, interviews, and documentation. The results of this study indicate that RJA manages its business based on Islamic values such as the application of employee SOPs which are full of Islamic values, contracts in muamalah, and ethics in doing business. SET-based accountability can also be seen in the RJA business such as giving donations to dakwah institutions, conducting social assistance for the poor, and gifts to orphans. This research was conducted at RJA Antang in May 2020.
\end{abstract}

Kata kunci : ABSTRAK

Akuntabilitas, Bisnis, Syariah, SET, RJA

\begin{abstract}
Penelitian ini bertujuan untuk mengetahui sistem pengelolaan bisnis yang diterapkan oleh Rumah Jahit Akhwat (RJA), di antaranya implementasi dan peranan akuntabilitas berbasis Sharia Enterprise Theory (SET). Penelitian ini menggunakan metode kualitatif dengan pendekatan fenomenologi. Subjek penelitian ini adalah owner, karyawan dan pelanggan RJA. Dengan melakukam observasi, wawancara dan dokumentasi secara langsung. Hasil penelitian ini menunjukkan bahwa RJA mengelola bisnisnya berdasarkan nilau-nilai Islam seperti penerapan SOP karyawan yang sarat akan nilai Islam, akad dalam muamalah, serta etika dalam berbisnis. Akuntabilitas berbasis SET juga bisa dilihat dalam bisnis RJA seperti pemberian sumbangan kepada lembaga dakwah, melakukan bansos bagi yang tidak mampu, dan memberikan hadiah kepada anak yatim. Penelitian ini dilakukan di RJA Antang pada Mei 2020.
\end{abstract}

Diterima: 12 Okrober 2020; Direvisi: 19 November 2020; Disetujui: 21 November 2020; Tersedia online: 18 Desember 2020.

How to cite: Putri, S. U. (2020). Analisis Akuntabilitas Berbasis Sharia Enterprise Theory untuk Pengembangan Bisnis Rumah Jahit Akhwat di Makassar. NUKHBATUL 'ULUM: Jurnal Bidang Kajian Islam, 6 (2), $187-203$. https://doi.org/10.36701/nukhbah.v6i2.242

Sri Ujiana Putri, Analisis Akuntabilitas Berbasis... 


\section{PENDAHULUAN}

Bisnis merupakan bagian dari kegiatan ekonomi dan mempunyai peranan yang sangat penting dalam rangka memenuhi kebutuhan manusia ${ }^{1}$. Kegiatan bisnis sangat berimplikasi terhadap kehidupan manusia baik dalam skala individu, sosial, regional, nasional maupun internasional ${ }^{2}$. Sebagai kegiatan yang menghasilkan barang dan jasa untuk memenuhi kebutuhan hidup masyarakat, pola dan perilaku bisnis telah banyak menjamur hampir di seluruh lapisan masyarakat, baik di kalangan atas, menengah dan kalangan bawah. Hal yang diharapkan tentu saja adalah mendapatkan keuntungan atau profit. Dengan adanya kebutuhan masyarakat akan suatu barang atau jasa maka bisnis akan muncul untuk memenuhinya dan keuntungan (profit) menjadi suatu keniscayaan dalam berbisnis ${ }^{3}$.

Sejarah mencatat bagaimana Rasulullah saw. yang dilahirkan di tengah lingkungan masyarakat yang maju dalam hal bisnis. Adanya dukungan internal dan eksternal sehingga beliau tumbuh menjadi sosok pebisnis yang ulet dan handal. Tentu saja Islam sebagai agama yang sempurna, dan syariat Islam sejatinya bertujuan untuk mengatur kemaslahatan hidup manusia ${ }^{4}$. Termasuk di dalamnya pemenuhan kebutuhan hidup (ekonomi) baik di dalam Al-Quran maupun hadis yang memberikan kebebasan kepada umatnya dalam menghasilkan mata pencaharian yang halal dan baik ${ }^{5}$, serta menghidari atau menjauhi yang haram. Dengan demikian, diperlukan metode pencarian dan pembelanjaan harta yang harus sejalan dengan syariat Islam, karena ia adalah bagian dari prinsip ekonomi Islam ${ }^{6}$, baik dalam berbisnis, dan lain sebagainya.

Sharia Enterprise Theory (SET) hadir dalam memberikan pertanggungjawaban, utamanya kepada Allah swt. (akuntabilitas horizontal) kemudian dijabarkan dalam bentuk pertanggungjawaban kepada manusia dan lingkungan alam (akuntabilitas vertikal). Konsep pertanggungjawaban yang ditawarkan dalam teori ini bukan sekedar pengembangan konsep pertanggungjawaban Enterprise Theory, melainkan sebagai hasil dari premis SET ), h.289

${ }^{1}$ Idri, Hadis Ekonomi:Ekonomi dalam Perspektif Hadis Nabi (Jakarta: Prenadamedia, 2015

${ }^{2}$ Norvadewi, Optimalisasi Peran Zakat dalam Mengentaskan Kemiskinan di Indonesia, Jurnal, 2012.

${ }^{3}$ Dyas Nur Fajrina, Analisis Penerapan Bisnis Berbasis Syariah pada Wirausaha Muslim, Skripsi, 2015.

${ }^{4}$ Usman, M. H., Aswar, A., \& Irawan, A. W., "Syariat Islam dan Kemaslahatan Manusia di Era New Normal pada Kegiataan Keagamaan dan Pendidikan”, FENOMENA 12, no. 1 (2020): h. 90.

${ }^{5}$ Novi Indriyani Sitepu,’Prilaku Bisnis Muhammad saw. Sebagai Enterpeneur dalam Filafat Ekonomi Islam" Human Falah 3,no.1 (Juni 2016)

${ }^{6}$ Iskandar, A., \& Aqbar, K., "Reposisi Praktik Ekonomi Islam: Studi Kritis Praktik Ekonomi Islam di Indonesia”, NUKHBATUL'ULUM: Jurnal Bidang Kajian Islam 5, no. 1 (2019): h. 52 . 
yang memiliki karakter transedental dan teleologicar. Dalam pandangan SET, stakeholders sebagai khalifah Allah swt. diberi amanah untuk mengelola sumberdaya dan mendistribusikannya pada seluruh makhluk di muka bumi secara adil ${ }^{8}$. Dari sini tampak SET dibangun atas premis bahwa; asas suatu ilmu ialah bersumber dari Al-Qur'an ${ }^{9}$ dan hadis ${ }^{10}$.

Banyak pengusaha muslim di zaman ini yang telah mencoba meneladani Rasulullah saw. dalam menjalankan bisnisnya. Namun, tidak sedikit yang tidak berkembang bahkan ada yang gulung tikar dalam usahanya. Lain halnya dengan Rumah Jahit Akhwat atau biasa disingkat RJA yang tampak semakin tumbuh dan berkembang. RJA sendiri dibangun dari suatu kesadaran bahwa semakin hari semakin banyak muslimah yang membutuhkan pakaian yang syar'i. Dengan melihat potensi dan pangsa pasar tersebut, maka RJA meniatkan untuk membangun usaha bisnisnya di atas prinsip-prinsip syariah.

Bisnis pakaian dan aksesoris muslimah ini semula berbentuk rumah yang menerima pesanan jahitan dari konsumen. Perlahan kini menjadi butik dengan brand produksi sendiri, dan juga telah melakukan kerjasama dengan brand yang lain serta sudah memiliki 7 cabang yang tersebar di Pulau Sulawesi. Dengan pencapaian omzet perbulan yang mencapai 2 milyar. Keunikan bisnis ini dibanding bisnis yang lain adalah bisnis ini merupakan bisnis keluarga yang didirikan dengan modal sendiri tanpa bantuan bank ${ }^{11}$. Hal itu dilakukan oleh kesadaran membangun bisnis "bebas riba", sebab umumnya pihak perbankan memberikan pinjaman dengan memperoleh manfaat dari nasabahnya. Ihwal riba dalam hal pinjam-meminjam, maka kaidah fikih yang berbunyi: "Setiap pinjaman (piutang) yang mendatangkan keuntungan (kemanfaatan), maka itu adalah riba"12, patut diperhatikan.

Metode penelitian yang digunakan pada penelitian ini adalah penelitian kualitatif dengan pendekatan fenomenologi yaitu metode yang akan menghasilkan data yang deskriptif berupa kata-kata tertulis atau lisan dengan

7 Iwan Triyuwono, Akuntansi Syariah Perspektif, Metodologi, dan Teori (Cet.IV;Depok:PTRajagrafindo persada,2015), h.358

${ }^{8}$ Siti Amerieska, Gugus Irianto, dan Didied P. Affandy," Akuntabilitas pada Baitul Maal Wat Tamwil ditinjau dari perspektif shari' ate enterprise theory" Ekonomi dan keuangan Islam 2, no.1 (Januari 2012).

${ }^{9}$ Syaripudin, A., “Al-Qur'an sebagai Sumber Agama Islam”, NUKHBATUL'ULUM: Jurnal Bidang Kajian Islam 2, no. 1 (2016): h. 138.

${ }^{10}$ Sudahnan, L. H., \& Yusram, M., "Kaidah dalam Interaksi dan Interpretasi terhadap Nasnas Tanda Hari Kiamat”, NUKHBATUL'ULUM: Jurnal Bidang Kajian Islam 5 no. 2 (2019): h. 74.

${ }^{11}$ Zakiyah Kartini (32 tahun), owner RJA Makassar, wawancara, Makassar, 22 Juli 2019.

${ }^{12}$ Wijaya, H., "Takyīf Fiqh Pembayaran Jasa Transportasi Online Menggunakan Uang Elektronik (Go-Pay Dan OVO)", NUKHBATUL'ULUM: Jurnal Bidang Kajian Islam 4, no. 2 (2018): h. 188. 
menelaah fenomena yang terjadi pada subjek penelitian atau subjek terteliti lapangan.

Dalam penelitian ini pula, penulis menggunakan teknik wawancara dan observasi lapangan untuk menghimpun dan mencerap data, kekhasannya pada proses in depth interview terhadap pengalaman hidup subjek terteliti lapangan ${ }^{13}$, serta melakukan analisis dari bahan-bahan tertulis sebagai sumber data penelitian (studi dokumentasi). Untuk itu, dalam melihat novelty (kebaruan) dari penelitian ini, maka dilakukan trace (penyelidikan) terhadap hasil-hasil penelitian terdahulu yang relevan atau proses menemukan gap research. Berikut disajikan hasil penelitian terdahulu di bawah ini:

Pertama, Analisis Penerapan Sharia Enterprise Theory pada Laporan Keuangan Menurut PSAK 101 (Studi Kasus Pada Bank Syariah Mandiri) oleh Nurul Barkah ${ }^{14}$. Penelitian ini menganalisis hasil penerapan Sharia Enterprise Theory yaitu dengan penerapan laporan nilai tambah pada laporan keuangan, khususnya perbankan syariah. Penerapan nilai tambah menghasilkan informasi mengenai total produktivitas perusahaan serta kontribusi dari masing-masing pihak yang terlibat dalam mengelola sumber daya perusahaan. Laporan nilai tambah bukan sebagai pengganti dari laporan laba rugi melainkan sebagai laporan keuangan tambahan atau pelengkap.

Kedua, Penerapan Tanggung Jawab Sosial Perbankan Syariah dalam Sudut Pandang Sharia Enterprise Theory Periode Tahun 2014 (Studi Pada Bank Muamalat dan Bank BNI Syariah) oleh Mega Putri Mayang Puspitasari ${ }^{15}$. Penelitian ini menganalisis tanggung jawab sosial perusahaan perbankan syariah berbasis pada konsep teori perusahaan.

Ketiga, Akuntabilitas pada Baitul Maal Wat Tamwil ditinjau dari perspektif Sharia Enterprise Theory oleh Siti Amerieska, Gugus Irianto, dan Didied P. Affandy. ${ }^{16}$ Penelitian ini bertujuan untuk menganalisis akuntabilitas yang dipraktekkan oleh lembaga keuangan mikro Islam, yaitu BMT.

Keempat, Analisis Laporan Pertanggungjawaban Perusahaan Terhadap Stakeholders dalam Perspektif Islam (Studi Kasus Pada Bank Syariah Bukopin

\footnotetext{
${ }^{13}$ Ramdani, F., \& Aswar, A., "Hablun Minannas Wanita Bercadar (Studi Fenomenologi Interaksi Sosial Wanita Bercadar di Kecamatan Manggala Makassar)", NUKHBATUL'ULUM: Jurnal Bidang Kajian Islam 6, no. 1 (2020): h. 109.

${ }^{14}$ Nurul Barkah, "Analisis Penerapan Syariah Enterprise Theory Pada Laporan Keuangan Menurut PSAK 01 (Studi Kasus Pada Bank Syariah Mandiri)" Thesis (Bandung: Perpustakaan Universitas Pendidikan Indonesia 2014)

${ }^{15}$ Mega Putri Mayang Puspitasari,"Penerapan Tanggung Jawab Social Perbankan Syariah dalam Sudut Pandang Shariah Enterprise Theory periode tahun 2014 Studi pada Bank Muamalat dan Bank BNI Syariah" Ekonomi Akuntansi 3, No.3 (2017).

${ }^{16}$ Siti Amerieska, Gugus Irianto, dan Didied P. Affandy," Akuntabilitas pada Baitul Maal Wat Tamwil ditinjau dari perspektif shari' ate enterprise theory" Ekonomi dan keuangan Islam 2, no.1 (Januari 2012).
} 
dan BRI Syariah) oleh Rahmi Farah Diba Zulhas ${ }^{17}$. Penelitian ini bertujuan untuk menganalisis kepatuhan bank syariah untuk mengungkapkan tanggung jawab sosial perusahaan dari perspektif Islam dengan menggunakan teori perusahaan syariah. Studi ini menunjukkan bahwa kedua bank telah memenuhi akuntabilitas vertikal kepada Tuhan dengan baik. Namun, pengungkapan akuntabilitas horisontal kepada pemangku kepentingan langsung dan tidak langsung serta sifatnya belum sepenuhnya tercapai.

Kelima, Analisis Pengungkapan Tanggung Jawab Sosial Perbankan Syariah dalam Perspektif Sharia Enterprise Theory (Studi Kasus di Bank BRI Syariah Palopo) oleh Suhardi M. Anwar dan Nur Adilah Rajab ${ }^{18}$. Penelitian ini bertujuan untuk mengetahui pengaruh Sharia Enterprise Theory terhadap pengungkapan tanggung tawab sosial syariah pada PT. Bank BRI Syariah Palopo. Hasil penelitian menunjukkan bahwa Sharia Enterprise Theory berpengaruh signifikan positif terhadap pengungkapan tanggung jawab sosial pada Bank BRI Syariah Cabang Palopo.

Dari keseluruhan hasil penelitian di atas, ditemukan persamaan dari sisi upaya investigasi ilmiah terhadap penerapan Sharia Enterprise Theory (SET) dalam akuntansi syariah. Perbedaan mendasar dari penelitian terdahulu terletak pada subjek dan lokus penelitiannya, di mana sebagian besar penelitian yang ada membahas tentang penerapan SET dalam perbankan syariah dan belum didapati kajian tentang penerapan SET dalam lembaga bisnis terkhusus RJA.

RJA menarik menurut peneliti karena bisnis ini semakin tumbuh dan berkembang serta omzetnya sudah mencapai 2 milyar dalam sebulan sebelum 10 tahun berdirinya usaha tersebut. Dengan demikian, hasil dari penelitian ini dapat berkontibusi dalam memperkaya kajian ekonomi Islam, khususnya di bidang bisnis.

\section{PEMBAHASAN}

\section{Akuntabilitas Berbasis Sharia Enterprise Theory dalam Bisnis}

SET merupakan suatu teori akuntansi tentang ekuitas atau kepemilikan tentang suatu entitas. Secara teoritis, dapat disebutkan teori-teori yang telah lahir sebelum SET ${ }^{19}$ adalah Proprietary Theory, Entity Theory, Residual Equity

\footnotetext{
${ }^{17}$ Rahmi Farah Diba Zulhas “Analisis laporan pertanggung-jawaban perusahaan terhadap stakeholders dalam perspektif islam (Studi Kasus Pada Bank Syariah Bukopin Dan BRI Syariah)" Jurnal Penelitian dan Pengembanngan Akuntansi 9, no.2 (2015).

${ }^{18}$ Suhardi M. Anwar dan Nur Adilah Rajab "Analisis pengungkapan tanggung jawab sosial perbankan syariah dalam perspektif syariah enterprise theory (studi kasus di Bank BRI Syariah Palopo), Jurnal Manajemen 4, no.2 (2018).

${ }^{19}$ Elvyra Handayani Soedarso"Penilaian kinerja fisik (materi) koperasi syariah menurut perspektif shariate enterprise theory dengan nilai tambah syariah dan zakat sebagai indicator" Riset Akuntansi dan Keuangan 1, no.3 (2010).
} 
Theory, Fund Theory, dan yang terakhir Enterprise Theory. SET adalah Enterprise Theory yang telah diinternalisasi dengan nilai-nilai Islam guna menghasilkan teori yang transendental dan lebih humanis.

Enterprise Theory merupakan teori yang mengakui adanya pertanggungjawaban yang tidak hanya kepada pemilik perusahaan saja melainkan kepada kelompok stakeholders yang lebih luas. Enterprise Theory mampu mewadahi kemajemukan masyarakat (stakeholders), hal yang tidak mampu dilakukan oleh Proprietary Theory dan Entity Theory ${ }^{20}$.

SET dilandasi oleh premis yang mengatakan bahwa manusia adalah khalifatullah fil ardh yang membawa misi menciptakan dan mendistribusikan kesejahteraan bagi seluruh manusia dan alam. Premis tersebut mendorong SET untuk mewujudkan nilai keadilan terhadap lingkungan manusia dan alam. Oleh karena itu, SET akan membawa kemaslahatan bagi stockholders, stakeholders, masyarakat dan lingkungan ${ }^{21}$. SET tidak hanya mementingkan kepentingan individu (dalam hal ini pemegang saham), tetapi juga pihak-pihak lain yang terkait. Dengan demikian, SET memiliki kepedulian yang besar pada stakeholders secara luas. Menurut SET, stakeholders yang paling tinggi adalah Allah swt. yang menjadi satu-satunya tujuan hidup manusia ${ }^{22}$. Stakeholder kedua dari SET adalah manusia, dan stakeholder yang terakhir adalah alam ${ }^{23}$. Hal ini sejalan dengan konsep maqāsid al-syarīiah yang mempertimbangankan kemaslahatan pembangunan manusia dan alam, dan bertujuan untuk kesejehteraan manusia itu sendiri ${ }^{24}$.

SET memiliki karakter keseimbangan yang menyeimbangkan nilai egoistik dengan nilai altruistik serta nilai materi dengan nilai spiritual ${ }^{25}$. Konsekuensi dari nilai keseimbangan ini menjadikan SET tidak hanya peduli pada kepentingan individu, tetapi juga pihak-pihak lainnya. Untuk itu, pandangan SET tentang akuntabilitas, menyatakan bahwa terdapat tiga dimensi hubungan akuntabilitas, yaitu dimensi hubungan pertama adalah kepada Allah swt. sebagai pencipta dan pemilik Tunggal dari seluruh sumber daya yang ada di

\footnotetext{
${ }^{20}$ Sigit Hermawan dan Restu Widya Rini,"Pengelolaan Dana Zakat, Infaq, dan Shadaqah Perspektif Shariah Enterprise Theory" Riset Akuntansi dan Keuangan Indonesia 1, no.1 (2016).

${ }^{21}$ Ririn Irmadariyani,"Implementasi Strategic Corporate Sosial Responsibility dalam Perspektif Sharia Enterprise Theory" Prosiding Seminar Nasional, Desember 2016.

${ }^{22}$ Iwan Triyuwono, "Mengangkat Sing Liyan Untuk Formulasi Nilai Tambah Syariah" Simposium Nasional Akuntansi X (2011).

${ }^{23}$ Iwan Triyuwono, "Mengangkat Sing Liyan Untuk Formulasi Nilai Tambah Syariah" Simposium Nasional Akuntansi X (2011).

${ }^{24}$ Iskandar, A., \& Aqbar, K., "Green Economy Indonesia Dalam Perspektif Maqashid Syari'ah”, Al-Mashrafiyah: Jurnal Ekonomi, Keuangan, dan Perbankan Syariah 3, no. 2 (2019): h. 92-93.

${ }^{25}$ Iwan Triyuwono, "Mengangkat Sing Liyan Untuk Formulasi Nilai Tambah Syariah" Simposium Nasional Akuntansi X (2011).
} 
dunia ini. Dengan demikian, yang berlaku dalam SET bahwa Allah swt. sebagai sumber utama, karena Dia adalah pemilik yang tunggal dan mutlak. Dengan ini dipahmi pula bahwa sumber daya yang dimiliki oleh manusia (stakeholders) pada dasarnya adalah amanah dari Allah swt. yang di dalamnya melekat sebuah tanggung jawab untuk menggunakan dengan cara dan tujuan yang ditetapkan oleh Sang Pemberi Amanah. Oleh karena itu, tujuan dari penggunaan sumber daya ini tidak lain adalah untuk mendapatkan mardatillāh. Tujuan ini dapat dicapai apabila si hamba menggunakan sumber daya dengan cara yang dapat menjadikan sumber daya itu menjadi rahmatan lil ālamīn ${ }^{26}$.

Dimensi hubungan akuntabilitas kedua adalah manusia dengan manusia, dibedakan menjadi dua kelompok yaitu direct stakeholders dan indirect stakeholders. Direct stakeholders merupakan pihak-pihak yang secara langsung memberikan kontribusi pada perusahaan. Sementara indirect stakeholders adalah pihak yang sama sekali tidak memberikan kontribusi kepada perusahaan, baik keuangan maupun non-keuangan, tetapi secara syariah merupakan pihak yang berhak untuk mendapatkan kesejahteraan dari perusahaan. Sementara golongan stakeholder terakhir atau dimensi hubungan akuntabilitas dari SET adalah alam. Alam adalah ekosistem vital yang memberikan kontribusi bagi kelangsungan hidup perusahaan. Sehubungan dengannya, Iskandar dan Aqbar menyebutkan bahwa dalam menjalankan ekonomi Islam, diperlukan kesadaran terhadap hablu min al-a 'alām wa al-bi'ah, yaitu memahami fungsi dan kondisi tanah, air, udara, tumbuh-tumbuhan, hewan, serta kaitannya dengan keberlangsungan kehidupan manusia $^{27}$.

Akuntabilitas SET merupakan akuntabilitas yang bersifat holistik karena meliputi dimensi hubungan manusia dengan Tuhan (akuntabilitas spiritual), dimensi hubungan manusia dengan lingkungan alam (akuntabilitas ekologi), dan dimensi hubungan manusia dengan sesama manusia (akuntabilitas ekonomi dan akuntabilitas sosial). Selain itu, dimensi hubungan akuntabilitas meliputi aspek spiritual, yang berlaku dalam hubungan manusia dengan Tuhan. Manifestasi akuntabilitas spiritual ini didasari bahwa semua aktivitas yang dilakukan adalah bernilai ibadah, dan amal kepada-Nya. Jalan yang ditempuh untuk melakukan ke dua hal tersebut masuk dalam kategori jihad di jalan-Nya. Salah satu jalan jihad tersebut dengan menerapkan prinsip-prinsip syariah ${ }^{28}$ (humanis, emansipatoris, transendental dan teleologikal) dalam aktivitas bisnis.

\footnotetext{
${ }^{26}$ Siti Amerieska "Akuntabilitas Pada Baitul Maal Wat Tamwil Ditinjau Dari Perspektif Shari'ate Enterprise Theory" Ekonomi dan keungan Islam 2, no.1 (Januari 2012): h.29.

${ }^{27}$ Iskandar, A., \& Aqbar, K., "Green Economy Indonesia Dalam Perspektif Maqashid Syari’ah”, Al-Mashrafiyah: Jurnal Ekonomi, Keuangan, dan Perbankan Syariah 3, no. 2 (2019): h. 92.

${ }^{28}$ Siti Amerieska, dkk, "Akuntabilitas Pada Baitul Maal Wat Tamwil Ditinjau Dari Perspektif Shari' ate Enterprise Theory” Jurnal Ekonomi \& Keuangan Islam 2 No. 1, Januari 2012
} 


\section{Konsep Akuntabilitas Berbasis SET dalam Bisnis RJA (Rumah Jahit Akhwat)}

Setiap bisnis harus memiliki konsep agar bisnis tersebut dapat terarah dan berkembang sesuai keinginan. Demikian pula RJA yang memiliki konsep dalam menjalankan bisnisnya. Dengan memahami aturan yang ditetapkan dalam Islam, RJA menerapkan aturan-aturan Islam dalam muamalah sehingga dapat berlaku adil untuk semua pihak, baik yang terlibat langsung maupun tidak ${ }^{29}$. Produk yang RJA tawarkan adalah pakaian muslim dan muslimah dari anak-anak hingga dewasa, baik produksi sendiri atau pun brand produk lain. Semua pakaian yang dijual adalah pakaian syar'i, tidak ada yang menampakkan aurat. RJA juga menjual aksesoris muslimah seperti kaos kaki, kaos tangan, masker, dan lain-lain. Bahkan, RJA sudah menjual bahan baku yaitu kain jika konsumen ingin menjahit sendiri atau butik yang membutuhkan kain untuk diolah menjadi pakaian ${ }^{30}$.

Konsep akuntabilitas dalam Islam sangat erat hubungannya dengan hisab (perhitungan) di hari pembalasan. Hisab yang dimaksud dalam arti umum yaitu berkaitan dengan kewajiban seseorang sebagai account kepada Allah swt. dalam segala hal yang berkaitan dengan perbuatan manusia ${ }^{31}$, sebagaimana firman Allah swt. dalam Qs. Al-Mudatstsir/74: 38,

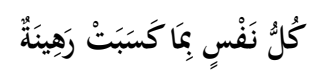

Terjemahnya:

"Tiap-tiap diri bertanggung jawab atas apa yang telah diperbuatnya"32.

Makna pertanggungjawaban (akuntabilitas) ini telah dipahami dan diterapkan dengan baik oleh RJA.

Dalam konteks akuntabilitas, manusia seakan-akan mengikat kontrak dengan Allah swt. Kontrak tersebut, dari dan kepada Allah swt. sebagai The Ultimate Principal yang menugaskan manusia untuk menyebarkan rahmat/kesejahteraan pada manusia lain dan alam ${ }^{33}$. Tugas inilah yang dipahami owner RJA dan menjadi salah satu tujuan didirikannya RJA. Menurutnya, tujuan didirikannya RJA dituturkannya bahwa:

"RJA bisa bermanfaat untuk orang banyak dan membuka lapangan pekerjaan terutama untuk kalangan akhawaat, dan kami melihat usaha ini sangat cocok untuk akhwat yang tidak perlu lagi berikhtilat" ${ }^{\prime 34}$.

Konskuensi dari sebuah penugasan adalah manusia harus bertanggung

${ }^{29}$ Zakiyah Kartini (32 tahun), owner RJA Makassar, wawancara, Makassar, 11 Mei 2020.

${ }^{30}$ Satriani (24 Tahun), Pengelola RJA, wawancara, Makassar, 15 Mei 2020.

${ }^{31}$ Rahmah Yulisa Kalbarini Dan Noven Suprayogi," Implementasi Akuntabilitas Dalam Konsep Metafora Amanah Di Lembaga Bisnis Syariah (Studi Kasus : Swalayan Pamella Yogyakarta)" JESTT 1, No. 7 (Juli 2014): h.507

${ }^{32}$ Departemen Agama RI, Al-Qur'an dan Terjemahannya, h. 577.

${ }^{33}$ Iwan Triyuwono, Akuntansi Syariah Perspektif, Metodologi,dan Teori (cet.IV; Jakarta: Rajawali Pers, 2015), h.342

${ }^{34}$ Zakiyah Kartini (32 tahun), owner RJA Makassar, wawancara, Makassar, 11 Mei 2020. 
jawab atas tugas yang dibebankan terhadapnya. Untuk itu, akuntabilitas yang dilakukan oleh managemen adalah akuntabilitas yang suci yaitu managemen menyajikan "persembahan" yang suci kepada Allah swt., agar persembahan ini diterima dan mendapatkan ridha-Nya, manajemen kepada Allah swt. ini diistilahkan akuntabilitas vertikal ${ }^{35}$. Konsep pertanggungjawaban telah dipahami oleh owner maupun karyawan RJA, sebagaimana wawancara yang dilakukan penulis terhadap owner RJA, melalui penuturannya bahwa:

"Pertanggungjawaban bukan hanya kepada manusia tetapi pada Allah juga tentunya, kami lebih menekankan pada amanah. Baru-baru kami mengadakan SO dengan tujuan menekankan pada tim akan kebutuhan mengeluarkan zakat. Begitu juga amanah HRD, kami wajibkan semua karyawan tarbiyah agar ruh dan prinsip bekerja tak melupakan ibadah karena kami merasa bertanggung jawab kepada karyawan dalam hubungannya juga pada Allah." ${ }^{36}$

Selain itu, wawancara juga dilakukan pada karyawan RJA yaitu berinisial SYN yang mengatakan bahwa:

"Tanggung jawab adalah amanah, kewajiban kami melakukan apa yang diamanahkan perusahaan karena Allah Maha Melihat"37.

Konsep pertanggungjawaban ini juga diterapkan dalam RJA, terlihat dari barang yang diproduksinya yaitu pakaian syar' $i$ yang mendukung muslimah dalam menjalankan salah satu perintah agamanya yaitu menutup aurat. Selain itu, para karyawan perempuannya pun semua menggunakan hijab. Tidak hanya itu, budaya operasional RJA tidak terluput dari penerapan nilai Islam sebagai pertanggungjawaban kepada Allah swt. seperti senantiasa mengucapkan "bismillah" diawal kegiatan, tidak merokok bagi karyawan laki-laki, salat tepat waktu, dan semua karyawan juga diwajibkan untuk menuntut ilmu agama setiap pekan. Demikian pula pengelolaan bisnis ini sangat memperhatikan hukumhukum yang berkaitan dengan muamalah. Inilah juga yang menjadi alasan owner RJA tidak berhenti belajar, setelah menyelesaikan studi di Sekolah Tinggi Ilmu Islam dan Bahasa Arab (STIBA) Makassar pada Prodi Perbandingan Mazhab, sekarang melanjutkan studi di UMS (Universitas Muhammadiyah Surakarta) pada Jurusan Ekonomi Syariah.

Distribusi kekayaan atau nilai tambah tidak hanya berlaku pada para partisipan yang terkait langsung atau partisipan yang memberikan kontribusi kepada bisnis RJA seperti: pemegang saham, karyawan, dan pemerintah. Akan tetapi pihak lain yang tidak terkait langsung dengan bisnis yang dilakukan RJA atau pihak yang tidak memberikan kontribusi keuangan dan skill juga mendapatkan bagian dari distribusi kekayaan tersebut. Premis yang mengatakan

${ }^{35}$ Iwan Triyuwono," Akuntansi Syariah:Implementasi Nilai Keadilan dalam format Metafora Amanah,"1 Akuntansi dan Auditing Indonesia 4, no.1 (2000)

${ }^{36}$ Zakiyah Kartini (32 tahun), owner RJA Makassar, wawancara, Makassar, 11 Mei 2020.

${ }^{37}$ Suriyana (31 tahun), Pengelola RJA Makassar, Wawancara, Makassar, 13 Mei 2020. 
bahwa manusia itu adalah khalīfatullāh fī al-ard yang membawa misi menciptakan dan mendistribusikan kesejahteran bagi seluruh manusia dan alam ialah premis yang mendorong RJA untuk senantiasa berusaha mewujudkan nilai keadilan terhadap manusia dan lingkungan alam. Keinginan untuk senantiasa membawa kemaslahatan bagi stockholders (pemegang saham), stakeholders, dan masyarakat serta lingkungan alam tanpa meninggalkan zakat, infak, dan sedekah sebagai manifestasi ibadah kepada Allah.

Owner RJA mengungkapkan bahwa bisnis ini tidak hanya mencari keuntungan sendiri namun sangat memeperhatikan kesejahteran bersama, sebagaimana penuturannya:

"Alhamdulillah beberapa karyawan dan penjahit sudah membangun rumah permanen mereka, hasil dari pendapatan di RJA, mengumpulkan uang panaik, beberapa dari mereka dari status mustahik bisa menjadi muzakki, dan tidak sedikit yang bisa membiayai kuliah sendiri, mengirimkan uang bulanan ke orang tua di kampung, membiaayai sekolah saudara mereka"38.

Senada dengan Owner RJA, SYN sebagai pengelola juga menyampaikan apa yang sudah didapatkan selama bekerja di RJA, melalui penuturannya:

"Alhamdulillah selama kerja di RJA betul-betul sangat membantu saya dan keluarga. Saya kerja di RJA waktu masih kuliah di semester 2. Untuk gaji bertahap, awalnya sih saya sangat bersyukur yang bisa menerima saya bekerja sambil kuliah untuk membantu biaya kuliah saya, nominal saya tidak permasalahkan tapi karena kepercayaan yang diberikan oleh owner, baru beberapa bulan bergabung sudah bisa dipercayakan mendapat bonus. Bonus pertama yang saya dapatkan belum seperti saat ini tapi itu sudah membuat saya sangat bersyukur karena awalnya berharap gaji berapa pun dan ternyata diberikan bonus bulanan. Selain gaji dan bonus, 'Alhamdulillah', owner mempercayakan kepada kami untuk memasukkan modal berapa pun ke RJA, kami anggap ini tabungan masa depan. Awalnya saya merasa tidak bisa menyisihkan karena biaya kuliah dan biaya di kampung menurut saya tidak bisa menyisihkan tapi karena motivasi dan adanya bonus akhirnya uang bonus itulah yang saya jadikan tabungan, mulai dari 1 juta-an hingga tahun berikutnya sudah bisa lebih dari itu karena adanya laba bulanan yang juga terkumpul. Intinya saya pribadi merasa sangat bersyukur atas kepercayaan yang diberikan RJA kepada kami, karena menurut kami kepercayaan adalah kunci utama mendapatkan kenyamanan dan kesejahteraan kerja"39.

Wawancara dengan karyawan lain berinisial SAD juga mengungkapkan hal yang sama:

"RJA sangat membantu kehidupan sehari-hari, bahkan sudah bisa bangun rumah serta membantu ekonomi keluarga dan saudara. RJA senantiasa memberikan hadiah atau pun bonus kepada saya. Semoga selalu diberikan kesempatan kerjasama dengan RJA"40.

Selain itu, STR sebagai pengelola RJA juga menuturkan bahwa:

\footnotetext{
${ }^{38}$ Zakiyah Kartini (32 tahun), owner RJA Makassar, wawancara, Makassar, 11 Mei 2020.

${ }^{39}$ Suriyana (31 tahun), Pengelola RJA Makassar, Wawancara, Makassar, 13 Mei 2020.

${ }^{40}$ Suardi (40tahun), karyawan RJA, Wawancara, Makassar, 15 Mei 2020
} 
"Awal kerja di RJA gaji saya kurang dari 1 juta yang naik secara berkala sampai sekarang sudah tembus angka 5 juta. Bonus selalu ada tiap bulan yang awalnya dalam bentuk dana diterima bulanan sekarang dalam bentuk emas yang diambil pertahunnya. Dari kerja di RJA, 'Alhamdulillah' saya bisa menyelesaikan kuliah (S1), membeli motor, dan memiliki tabungan. Bonus lain yang biasa saya dapat juga adalah sering diikutkan acara seminar maupun pelatihan tentang bisnis yang dibiayai oleh RJA"41.

Dari wawancara yang dilakukan di atas, tergambarkan bahwa RJA telah berupaya mendistribusikan kekayaan kepada semua pihak yang terkait dengan bisnisnya dan mensejahterakan kehidupan mereka beserta keluarganya. Namun, ini tidak membuat RJA lupa akan kemaslahatan masyarakat atau pun lingkungannya. Ini bisa dilihat dari kegiatan yang dilakukan RJA, seperti menjadi sponsor kegiatan keagamaan, memberikan donasi untuk proposal permintaan dana, bakti sosial dan memberikan baju lebaran untuk anak yatim yang terlantar adalah kegiatan rutin yang dilakukan RJA sebagai bentuk pertanggungjawaban vertikal kemudian dijabarkan secara horisontal. Hal ini telah sesuai dengan perintah Allah swt. dalam Qs. Al-Baqarah/2: 195,

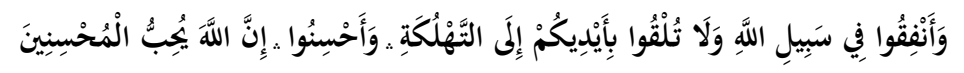

Terjemahan:

"Dan belanjakanlah (harta bendamu) di jalan Allah, dan janganlah kamu menjatuhkan dirimu sendiri ke dalam kebinasaan, dan berbuat baiklah, karena Sesungguhnya Allah menyukai orang-orang yang berbuat baik"42.

Pertanggungjawaban yang dijabarkan secara horisontal tidak hanya kepada manusia tapi juga kepada lingkungan/alam. Terlihat dari SOP (standard operating procedure) karyawan toko untuk senantiasa membersihkan toko sebelum buka dan tutup, serta menjaga kebersihannya juga memastikan tidak ada debu yang menempel di produk yang dipajang maupun area lain di toko. Ini dibuktikan dari pernyataan pelanggannya:

"Tokonya bersih, barang-barang tersusun rapi, dingin jadi suka belanja disini.

Selain karena dekat dari sekolah juga"43.

Hal ini tidak hanya berlaku di toko, namun area produksi juga menerapkan SOP untuk kerapian dan kebersihan, dengan slogan "LISA DARA APIK” (Lihat Sampah Ambil, Tidak Rapi, Atur dan Rapikan). Dalam produksi juga sebisa mungkin penjahit tidak menyisakan kain, kain-kain potongan digunakan untuk menjahit pakaian anak-anak, cadar lepas, masker, dan lain lain. Hal ini sangat efisien dalam mengurangi sampah hasil produksi. Sejatinya, slogan tersebut adalah merupakan dakwah yang digaungkan oleh organisasi Wahdah Islamiyah ke masyarakat yang juga mendukung program pemerintah Kota

\footnotetext{
${ }^{41}$ Satriani (24 Tahun), Pengelola RJA, wawancara, Makassar, 15 Mei 2020.

${ }^{42}$ Departemen Agama RI, Al-Qur'an dan Terjemahannya, h. 31.

${ }^{43}$ Saskia Aurhodia (13 Tahun), konsumen RJA, Wawancara, Makassar, 21 Mei 2020
} 
Makassar dengan programnya "Makassar Tidak Rantasa"44. Adapun owner RJA sendiri adalah seorang kader Wahdah Islamiyah Makassar.

\section{Peranan Akuntabilitas Berbasis SET dalam Pengembangan Bisnis RJA}

Tidak dipungkiri bahwa salah satu tujuan dibukanya bisnis adalah untuk mendapatkan profit dalam bentuk uang atau materi. Dari penghasilan inilah yang kemudian diputar lagi untuk mendapatkan uang dan begitu seterusnya. Dari uang diputar sedemikian rupa dan dirubah menjadi uang lagi. Sederhananya, bisnis yang dilakukan oleh manusia pada dasarnya mentransformasikan materi untuk menjadi materi yang lebih besar. Namun, tidak demikian pada bisnis yang dijalankan oleh RJA. Tujuan utamanya adalah membantu para muslimah menutup auratnya dan sekaligus sebagai bentuk ibadah, dengan tetap mendapatkan keuntungan. Disamping mendapatkan keuntungan dalam bentuk materi, owner RJA juga merasakan kesenangan sebagaimana yang diungkapkannya:

“Ada kebahagiaan yang kami rasakan, ketika melihat muslimah yang dulunya tak berhijab syar'i kini mengenakan busana syar'i yang dengannya kami berharap usaha ini bisa juga kami jadikan syi'ar da'wah di lapisan masyrakat" ${ }^{\prime 5}$. Juga pernyataan yang senada dari owner RJA lainnya:

"Selalu ada kesyukuran dan kesenangan saat melihat wajah-wajah itu, wajahwajah polos yang merindukan sosok seorang ayah dan ibu. Kami merasa bangga dan bahagia karena turut andil memberikan senyuman di wajah mereka. Meski hanya sedikit, setidaknya kado lebaran yatim ini bisa bermanfaat untuk anakanak. Walaupun omzet penjualan tidak seperti tahun-tahun sebelumnya karena wabah Covid-19, kami sadari ini ujian kita bersama sehingga tetap melaksanakan kegiatan tahunan ini, bahkan menjadi penyemangat kami untuk selalu menebar manfaat" ${ }^{46}$

Pada sitatan teks wawancara di atas menggambarkan perasaan seanang. Kesenangan di sini adalah kesenangan psikis (jiwa) atau kepuasan batin, bukan kesenangan sebagaimana yang dipahami oleh utilitarianisme. Bagi utilitarianisme, kesenangan tersebut dipahami sebagai utility yaitu dalam pengertian materi. Jadi, kesenangan menurut utilitarianisme adalah kesenangan materi ${ }^{47}$. Ungkapan owner RJA di atas juga menunjukkan bahwa apa yang dilakukan sebetulnya merupakan salah satu bentuk ibadah kepada Allah swt., dan ini berkaitan dengan aspek spiritual. Artinya apa yang dilakukan oleh owner RJA dalam bisnisnya, sebetulnya adalah bagian yang tidak terpisahkan dari orientasi

${ }^{44}$ Alamsyah, A., Damis, R., \& Hamsyah, H. B., "Dukungan Organisasi Islam "Wahdah Islamiyah" Terhadap Program Makassarta Tidak Rantasa", Sulesana: Jurnal Wawasan Keislaman 11, no. 1 (2017): h. 28-30.

${ }^{45}$ Zakiyah Kartini (32 tahun), owner RJA Makassar, wawancara, Makassar, 11 Mei 2020.

${ }^{46}$ Zakiyah Kartini (32 tahun), owner RJA Makassar, wawancara, Makassar, 11 Mei 2020.

${ }^{47}$ Iwan Triyuwono, "Mengangkat Sing Liyan Untuk Formulasi Nilai Tambah Syariah" Simposium Nasional Akuntansi X (2011) 
kehidupan ibadah.

Proses bisnis yang dilakukan owner RJA adalah selalu menganggap karyawannya sebagai saudaranya sendiri. Rasa persaudaraan inilah yang berlangsung sepanjang proses usahanya, mulai persiapan hingga bagi hasil produksi atau usaha. Tidak hanya rasa persaudaraan yang muncul, rasa senang juga ada pada proses awal hingga akhir. Rasa senang ini secara alami muncul karena semata-mata kuatnya rasa persaudaraan. Tidak dipungkiri kadang terjadi konflik, namun semua bisa diselesaikan dengan terbuka. Rasa senang yang diekspresikan dalam keceriaan di wajah para karyawan RJA merupakan bagian lain yang selalu ada dalam proses bisnis di RJA. Rasa ini sangat membantu para karyawan, penjahit maupun pengelola untuk bekerja tanpa lelah dan dengan motivasi yang tinggi. Sebagaimana yang diungkapkan salah seorang karyawannya berinisial SYN:

" Satu hal yang saya sangat hargai di RJA adalah ukhuwah, RJA Antang dibuka saat saya direkrut masuk RJA, dan diberi kepercayaan oleh owner bersama ukhty khadijah untuk mengelolanya. Banyak pengalaman dan saya merasa RJA adalah usaha kami juga" ${ }^{48}$

Hal yang sama juga diungkapkan oleh owner RJA:

“Karyawan kami adalah mereka yang selama ini membantu majunya usaha yang kami jalankan. Merekalah yang setiap hari melayani para customer, menyiapkan segalanya, mengatur dan mendistribusikan paket-paket yang telah diproduksi jauh-jauh hari. Mereka bukan hanya menjadi partner kerja kami selama ini tapi sudah kami anggap sebagai satu keluarga yang wajib kami hargai dan patut kami apresiasi"49.

Dari sitatan teks wawancara di atas, dapat disimpulkan bahwa bisnis RJA menghasilkan tiga hal, yaitu: rasa altruistik dan senang karena menyaksikan para pelanggannya mampu menjalankan perintah agama melalui bisnis yang dijalankan, selain rasa altruistik ada rasa persaudaraan yang begitu kental. Dengan rasa persaudaraan yang kuat, rasa ikhlas pun begitu mudah muncul dengan sendirinya. Ini yang membuat para karyawan bekerja dengan ulet, seakanakan bisnis milik mereka sendiri. Dengan demikian keuntungan materi juga semakin berkembang. Walhasil owner RJA pun menuturkan keberkahan yang dirasakannya sebagai berikut:

"Semakin banyak dikeluarkan, 'Alhamdulillah usaha semakin berkembang. Semakin banyak menggaji karyawan juga semakin tinggiji profit, begitu juga dengan penjahit-penjahit, semakin sejahtera dengan sistem yang RJA terapkan. Ini menjadi motivasi sendiri dan semangat di RJA untuk senantisa menebar manfaat' ${ }^{\prime \prime}$.

Menurut owner RJA, bisnisnya semakin berkembang ketika banyak

\footnotetext{
${ }^{48}$ Suriyana (31 tahun), Pengelola RJA Makassar, Wawancara, Makassar, 13 Mei 2020.

${ }^{49}$ Zakiyah Kartini (32 tahun), owner RJA Makassar, wawancara, Makassar, 11 Mei 2020.

${ }^{50}$ Zakiyah Kartini (32 tahun), owner RJA Makassar, wawancara, Makassar, 11 Mei 2020.
} 
mengeluarkan zakat maupun bantuan kepada sesama, dan profit semakin meningkat ketika memberikan banyak bonus-bonus untuk karyawan. Dengan demikian, inilah yang menjadi motivasi tersendiri agar senantiasa menebar manfaat kepada semua mahluk Allah 'Azza wa Jalla. Sehubungan dengan ini, Usman dan Aswar menyebutkan bahwa keberkahan, keamanan, kemakmuran, dan ketentraman hidup diperoleh tatkala manusia mengimplementasikan kehidupan berislam dengan baik dalam kesehariannya ${ }^{51}$.

\section{KESIMPULAN}

RJA (Rumah Jahit Akhwat) menerapkan aturan-aturan yang sesuai dengan konsep bisnis Islam dalam mengelola bisnisnya. Mulai dari bahan baku yang dipastikan kehalalannya, produksi, pemasaran, transaksi dan lain-lain. RJA senantiasa memperhatikan aturan-aturan muamalah yang terdapat dalam AlQur'an dan sunah Rasulullah saw. Akuntabilitas dalam Islam telah diimplementasikan dengan baik oleh RJA. RJA menyatakan bahwa akuntabilitas sebagai bentuk pertanggungjawaban terhadap apa yang dikelola kepada Allah swt. Akuntabilitas tidak hanya terbatas dalam konteks spiritual, tetapi juga merupakan pertanggungjawaban yang diformulasikan ke dalam sarana operasional untuk mencapai rida Allah swt.

Pengejewantakan SET (Sharia Enterprise Theory) juga telah diterapkan oleh RJA. Bisnis ini senantiasa mengeluarkan zakat dan memperhatikan etika bisnis sebagai bentuk pertanggungjawaban kepada Allah swt. Akuntabilitas vertikal ini kemudian dijabarkan dalam bentuk akuntabilitas horizontal. Senantiasa memberikan apresiasi kepada karyawannya, pemberian sumbangan kepada lembaga dakwah, melakukan bansos bagi yang tidak mampu, dan memberikan hadiah kepada anak yatim merupakan bentuk pertanggungjawaban secara horizontal. Namun, tidak sampai di situ, RJA juga senantiasa menjaga kebersihan lingkungannya dan meminimalkan sampah yang dihasilkan dari produksi produk, yakni mengamalkan slogan "LISA DARA APIK" (Lihat Sampah Ambil, Tidak Rapi, Atur dan Rapikan). Slogan tersebut merupakan dakwah organisasi Wahdah Islamiyah di masyarakat yang juga mendukung program pemerintah Kota Makassar yakni, "Makassar Tidak Rantasa".

\section{DAFTAR PUSTAKA}

Alamsyah, A., Damis, R., \& Hamsyah, H. B. (2017). Dukungan Organisasi Islam "Wahdah Islamiyah" Terhadap Program Makassarta Tidak Rantasa'. Sulesana: Jurnal Wawasan Keislaman, 11(1), 28-46.

${ }^{51}$ Usman, M. H., \& Aswar, A., "Korelasi Kehidupan Berislam Masyarakat Desa Baruga dengan Kemakmuran, Keamananan dan Ketentraman Hidup. Al-Din: Jurnal Dakwah dan Sosial Keagamaan 6, no. 1 (2020): h. 8-12. 
Amerieska, S., Irianto, G., \& Affandy, D. P. (2012). Akuntabilitas Pada Baitul Maal Wat Tamwil Ditinjau Dari Perspektif Shari'ate Enterprise Theory. Jurnal Ekonomi \& Keuangan Islam, 2(1), 27-39.

Anwar, S. M., \& Rajab, N. A. (2018). Analisis Pengungkapan Tanggung Jawab Sosial Perbankan Syariah Dalam Perspektif Syariah Enterprise Theory (Studi Kasus Di Bank BRI Syariah Palopo). Jurnal Manajemen STIE Muhammadiyah Palopo, 4(2). http://dx.doi.org/10.35906/jm001.v4i2.275

Barkah, Nurul (2014). Analisis Penerapan Syariah Enterprise Theory Pada Laporan Keuangan Menurut PSAK 01 (Studi Kasus Pada Bank Syariah Mandiri). Thesis (Bandung: Perpustakaan Universitas Pendidikan Indonesia).

Departemen Agama, R. I. (2017). Al-Qur'an dan terjemahan. Jakarta: CV Darus Sunnah.

Fajrina, D. N. (2015). Analisis Penerapan Bisnis Berbasis Syari'ah Pada Wirausaha Muslim (Studi Pada Wirausaha Muslim Di Perumahan Kaliwungu Indah-Kendal) (Doctoral dissertation, UIN Walisongo).

Hermawan, S., \& Rini, R. W. (2016). Pengelolaan Dana Zakat, Infaq, dan Shadaqah Perspektif Shariah Enterprise Theory. Riset Akuntansi dan Keuangan Indonesia, 1(1), 12-24. http://dx.doi.org/10.23917/reaksi.v1i1.1974

Idri. (2015). Hadis Ekonomi: Ekonomi dalam Perspektif Hadis Nabi. Jakarta: Prenadamedia.

Irmadariyani, R. (2016). Implementasi Strategic Corporate Social Responsibility Dalam Perspektif Shari'ah Enterprise Theory. UNEJ e-Proceeding, 842851.

Iskandar, A., \& Aqbar, K. (2019). Reposisi Praktik Ekonomi Islam: Studi Kritis Praktik Ekonomi Islam di Indonesia. NUKHBATUL'ULUM: Jurnal Bidang Kajian Islam, 5(1), 39-53. https://doi.org/10.36701/nukhbah.v5i1.68

Iskandar, A., \& Aqbar, K. (2019). Green Economy Indonesia Dalam Perspektif Maqashid Syari'ah. Al-Mashrafiyah: Jurnal Ekonomi, Keuangan, dan Perbankan Syariah, 3(2), 83-94. http://dx.doi.org/10.24252/almashrafiyah.v3i2.9576

Kalbarini, R. Y., \& Suprayogi, N. (2014). Implementasi Akuntabilitas dalam Konsep Metafora Amanah di Lembaga Bisnis Syariah (Studi Kasus: Swalayan Pamella Yogyakarta). Jurnal Ekonomi Syariah Teori dan Terapan, 1(7). http://dx.doi.org/10.20473/vol1iss20147pp506-517

Norvadewi, N. (2012). Optimalisasi Peran Zakat dalam Mengentaskan Kemiskinan Di Indonesia. Mazahib, 1O(1). http://dx.doi.org/10.21093/mj.v10i1.111 
Puspitasari, M. P. M. (2017). Penerapan Tanggung Jawab Sosial Perbankan Syariah Dalam Sudut Pandang Shariah Enterprise Theory Periode Tahun 2014 Studi Pada Bank Muamalat dan Bank BNI Syariah. Jurnal Ekonomi Akuntansi, 3(3), 647-661.

Ramdani, F., \& Aswar, A. (2020). Hablun Minannas Wanita Bercadar (Studi Fenomenologi Interaksi Sosial Wanita Bercadar di Kecamatan Manggala Makassar). NUKHBATUL'ULUM: Jurnal Bidang Kajian Islam, 6(1), 105-121. https://doi.org/10.36701/nukhbah.v6i1.114

Sitepu, N. I. (2016). Prilaku Bisnis Muhammad Saw. Sebagai Entrepreneur dalam Filsafat Ekonomi Islam. HUMAN FALAH: Jurnal Ekonomi dan Bisnis Islam, 3(1), 18-33.

Soedarso, E. H. (2013). Penilaian Kinerja Fisik (Materi) Koperasi Syari'ah Menurut Perspektif Shari'ate Enterprise Theory Dengan Nilai Tambah Syari'ah dan Zakat Sebagai Indikator. Jurnal Riset Akuntansi dan Keuangan, 1(3), 194-214. https://doi.org/10.17509/jrak.v1i3.6701

Sudahnan, L. H., \& Yusram, M. (2019). Kaidah dalam Interaksi dan Interpretasi terhadap Nas-nas Tanda Hari Kiamat. NUKHBATUL'ULUM: Jurnal Bidang Kajian Islam, 5(2), 64-87. https://doi.org/10.36701/nukhbah.v5i2.85

Syaripudin, A. (2016). Al-Qur'an sebagai Sumber Agama Islam. NUKHBATUL'ULUM: Jurnal Bidang Kajian Islam, 2(1), 132-139. https://doi.org/10.36701/nukhbah.v2i1.9

Triyuwono, I. (2015). Akuntansi Syariah Perspektif, Metodologi dan Teori. Jakarta: Raja Grafindo Persada.

Triyuwono, I. (2011). Mengangkat "Sing Liyan" untuk Formulasi Nilai Tambah Syari'ah. Jurnal Akuntansi Multiparadigma, 2(2), 186-200. http://dx.doi.org/10.18202/jamal.2011.08.7116

Triyuwono, I. (2000). Akuntansi Syari'ah: Implementasi Nilai Keadilan dalam

Format Metafora Amanah. Jurnal Akuntansi dan Auditing Indonesia, 4(1), 1-109.

Usman, M. H., Aswar, A., \& Irawan, A. W. (2020). Syariat Islam dan Kemaslahatan Manusia di Era New Normal pada Kegiataan Keagamaan dan Pendidikan. FENOMENA, 12(1), 89-106. https://doi.org/10.21093/fj.v12i1.2456

Usman, M. H., \& Aswar, A. (2020). Korelasi Kehidupan Berislam Masyarakat Desa Baruga dengan Kemakmuran, Keamananan dan Ketentraman Hidup. Al-Din: Jurnal Dakwah dan Sosial Keagamaan, 6(1). https://doi.org/10.35673/ajdsk.v6i1.845.

Wijaya, H. (2018). Takyīf Fiqh Pembayaran Jasa Transportasi Online Menggunakan Uang Elektronik (Go-Pay Dan 
NUKHBATUL 'ULUM : Jurnal Bidang Kajian Islam

Vol. 6, No. 1 (2020) : Hal. 187-203

NUKHBATUL

ULUM

Website: https://journal.stiba.ac.id

ISSN : 2685-7537 (online); 2338-5251 (Printed)

OVO). NUKHBATUL'ULUM: Jurnal Bidang Kajian Islam, 4(2), 187203. https://doi.org/10.36701/nukhbah.v4i2.46

Zulhas, R. F. D. (2015). Analisis Laporan Pertanggungjawaban Perusahaan terhadap Stakeholders dalam Perspektif Islam (Studi Kasus pada Bank Syariah Bukopin dan Bri Syariah). Akuntabilitas, 9(2), 207-228. 